\title{
Evaluation of Salinity in Some Soils of Irrigated Brack -Ashkada Agriculture Project, Fezzan, Libya
}

\author{
${ }^{1}$ Mansour A. Salem, ${ }^{2}$ Latif H. Al-ethawi
}

\begin{abstract}
The aim of the study was to investigate and evaluate the occurrence of salinity in two soil profiles in irrigated soils of a 30 years long Brack - Ashkada agriculture project and classify their degree of salinity. The study was carried on in well No. 6 which covers twelve farms. Soil pH, Electrical Conductivity (EC) and Exchangeable Sodium Percent (ESP) were measured at $25^{\circ} \mathrm{C}$; $\mathrm{pH}$ of soil samples ranged between 7.01 - 8.00; Electrical Conductivity (EC) is between $0.513-3.540 \mathrm{ds.m^{-1 }}$; and the Exchangeable Sodium Percent were ranged between $0.72-12.84$. The $\mathrm{pH}$ of the soils that had been influenced by salinity farms 8 and 9 is 7.49 8.05, EC 1.076 - 4.421. ESP is 4.03 - 17.56 for the second and first soil depths respectively. According to the American classification of soil salinity, five sites which represent $8.3 \%$ of the studied sites were found either salted or effected by salt.
\end{abstract}

Index Terms - EC, ESP, $p H$, salinity.

\section{Introduction}

Salinity refers to the total concentration of all salts either in water or in soil. It refers to the amount of soluble salt in soil such as sulphates $\left(\mathrm{SO}_{4}\right)$, carbonates $\left(\mathrm{CO}_{3}\right)$ and chlorides $(\mathrm{Cl})$ [1]. Salinization of land and water resources is a major land degradation issue in the world today. It can be the result of both natural occurrence and man-made. The salinity problems occur in non-irrigated lands as a result of water losses through evaporation and transpiration, possibly salt input through rain and seawater drift, or it can be developed due to careless usage of several fertilizers. Soils containing excess salts occur naturally in arid and semiarid climates. Also, irrigation with saline water or over-irrigation causes capillary movements of hidden salts from lower layers in the soil [2]. Evaporation and transpiration reduce the water content of soil by removing pure water as vapour. Losses of water concentrate the solutes that are left behind in the soil solution. Salt concentration may be increased further when there is no opportunity to flush out and drain the accumulated salts [3]. Irrigated agriculture also depletes and pollutes water supplies in many places, increasing of irrigation efficiency which is being sought to conserve water to reduce drainage, waterlogging and secondary salinization, and to mitigate some of the water pollution associated with irrigated agriculture [4]. Irrigation induced soil salinization affects agricultural production negatively in many parts of the world and requires close monitoring and control [5]. The adverse effect of irrigation water quality on the physical properties of soil is associated with the accumulation of sodium ion on the soil exchange complex which imparts instability to the soil aggregation and whose disruption is followed by dispersion of clay particles resulting in clogging soil pores. It can be used under specific conditions which include the tolerance of crops to salts, chemical and physical properties of soil, irrigation methods, and climate conditions in the region [6]. In arid areas or in areas where less rainfall occurs or saline irrigation water is used, soluble salts are more likely to accumulate and remain near the soil surface resulting in high electrical conductivity. The lack of adequate water resources in agricultural lands particularly in arid and semiarid areas force many farmers worldwide to use water with relatively high salt concentration to irrigate crops [7] Soil salinity in arid and semi-arid regions occurs as a result of several factors including high temperature, low rainfalls, rise in salty water-table, capillary rise in groundwater, soil type, water use, irrigation factors and flooding. Soil salinity increases between irrigation periods due to evapotranspiration [8], [9] Soil texture plays an important role in aspects of irrigation and strongly correlated with a soils ability to percolate water and the ability of soil's adsorb or absorb chemical ions [10]. Clay soils can slow drainage of water due to its smaller pore diameters and have relatively high water holding capacities, whereas the sandy soils have naturally occurring greater leaching fractions, correspondingly sandy soils can withstand higher salinity irrigation water as more of the water and hence salts are leached beneath root zone [11]. Ion imbalance is another important consequence of the salinity induced responses in the plant. The imbalance induces the increased accumulation of $\mathrm{Na}^{+}$that may replace other ions such as $\mathrm{k}^{+}$and $\mathrm{Ca}^{++}$which cause the impairment of the general physiological activity of plants [12], [13]. Crop production can suffer when salts accumulate in the soil root environment by increasing the osmotic potential of the soil solution which decreases a crop ability to extract water and results in suppressed plant growth and decreased yield [14] Soils are considered saline if they contain salt in a concentration sufficient enough to interfere with the growth of most plant species. It can be estimated by extracting the solution from a saturated soil sample and measuring the ability of the solution on 
conduct electricity [15]. Poor drainage and sustainable water logging of soil is built up salt in the soil profile causing stress of plants. Lastly, all poorly drained or non-drainage soils in arid region becomes saline [16], [17].

\section{Materials and Methods}

This study was carried out on Brack - Ashkada agricultural project at Fezzan area which represents about $725000 \mathrm{~km}^{2}$, and located in Southern - West corner of Libya between North latitudes $23^{\circ}$ to $28.5^{\circ}$ and East longitudes $10^{\circ}$ to $16^{\circ}$, with an altitude of $400 \mathrm{~m}$ above sea level [18]. This agriculture project built in 1975 , It contains 24 wells each well contains 12 farms; the area of each farm is about 10 hectares. Soil of the experimental area is mostly sand loamy soil, fertile and has very good drainage system. We choose well No. 6 as we observe it is affected by salt. Two soil samples each about $1.0 \mathrm{~kg}$ were taken from each farm of this well in polythene bags from different sites randomly, from two soil depths $(0-30$ and $30-60 \mathrm{~cm})$ with three replicates for each depth. Soil samples were initially prepared by air - drying and passing through $2 \mathrm{~mm}$ sieve for determination of EC, $\mathrm{pH}$, and ESP were measured as described in [19]. Soil samples were also taken from uncultivated soil (virgin soil) close to the study site as a reference. The same parameters were measured beside the Cation Exchange Capacity (CEC), Organic matter (OM), and Calcium Carbonate Percentage $(\mathrm{CaCO} \%)$ for comparison. Groundwater sample was also taken from the same well which irrigated the farms, $\mathrm{pH}$, EC, and Total Dissolved Salts (TDS) were measured as described in [20]. The objective of the study is to quantify the salinity levels in the profiles of soils that had been cultivated over 30 years.

\section{Results And Discussion}

The experimental site is located in arid region where evapotranspiration is high and rainfall is very rare for plant water requirement growth. Therefore irrigation is definitely necessary for crop production. Sprinkler method is used for the irrigation of the farms. The quality characteristics of water used for irrigation were as follows: $\mathrm{pH}$ is 7.03 , EC is about $0.757 \mathrm{ds} \cdot \mathrm{m}^{-1}$, and the TDS is about $0.484 \mathrm{~g} . \mathrm{l}^{-1}$. This quality of water is considered good for the irrigation. It had been reported that no saline water has, EC $<0.7 \mathrm{ds} . \mathrm{m}^{-1}$ and a TDS $<0.5$ $\mathrm{g}^{-1}$, while the saline water is categorized as water with an $\mathrm{EC}>3.0 \mathrm{ds} \cdot \mathrm{m}^{-1}$ [21], [22]. The results show the $\mathrm{pH}$ of soil samples for the cultivated area were between 7.10 in farm B10 and 8.05 in farm A8 at the first depth (0$30 \mathrm{~cm}$ ), whereas in the second depth $(30-60 \mathrm{~cm}$ ), is 7.01 in farm B10 and 8.0 in farm A6 (fig. 1). The result indicated that about $77 \%$ of the samples has a $\mathrm{pH}$ range of $7.20-7.60$, Soils samples slightly alkaline in reaction and showed the alkaline $\mathrm{pH}$ was possibly due to the presence of high $\mathrm{CaCO}_{3}$, as soils of the survey area were calcareous in nature. The soil reactions $(\mathrm{pH})$ of uncultivated soils were 7.0, (Table I). These results are compatible with the results reported by [23], [9] Soils can appear in a wide range of $\mathrm{pH}$, although they are normally neutral with a slight tendency towards alkalinity [24]. However, soil which is effected by high sodium content have higher $\mathrm{pH}$ and the rising of the $\mathrm{pH}$ in cultivated soils is due to the reaction of water with soil where the $\mathrm{OH}^{-}$ion is dominated.

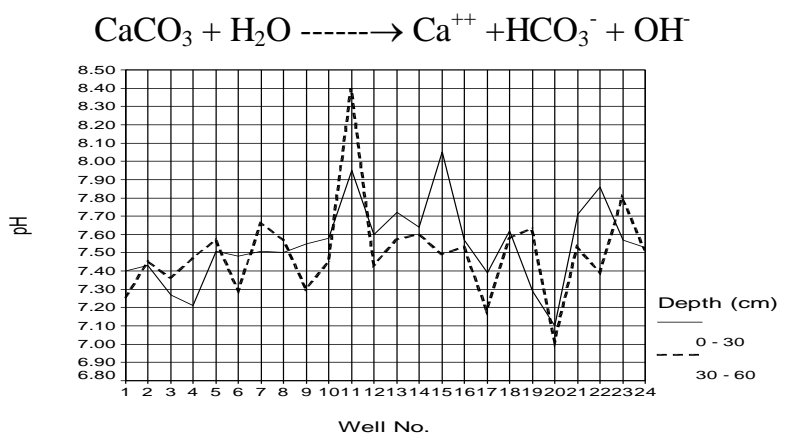

Fig. 1. pH of cultivated soil sample

It had been reported that slight salinity soil had $\mathrm{pH} 7$ to 8 , moderate saline had $\mathrm{pH} 8$ to 8.5 and strong salinity is between 8.5 to 9.0 [25].

Table I. SOME PHYSICAL AND CHEMICAL PROPERTIES OF VIRGIN SOIL SAMPLE

\begin{tabular}{ccc}
\hline Parameter & \multicolumn{2}{c}{ Depth $(\mathbf{c m})$} \\
& $0-30$ & $30-60$ \\
\hline Organic matter \% & 0.53 & 0.46 \\
$\mathrm{pH}$ & 7.01 & 7.00 \\
$\mathrm{C}_{\mathrm{a}} \mathrm{CO} 3 \%$ & 1.25 & 1.5 \\
$\mathrm{CEC}(\mathrm{meq} / 100 \mathrm{~g}$ soil) & 60 & 64 \\
$\mathrm{ESP}\left(\mathrm{meq}^{-1}\right)$ & 3.5 & 0.8 \\
EC ds.m & 5.21 & 1.05 \\
\hline
\end{tabular}


Electrical conductivity (EC) is the most popular and simple way to measure the soil salinity, It is used to measure of dissolved salts in irrigation water or soil solution, higher EC equates to Saltier soil. Measurement of soil EC is generally accepted as the most effective method for quantification of soil salinity [1]. The EC of soil samples at $25^{\circ} \mathrm{C}$ for the first soil depth $(0-30 \mathrm{~cm})$ was between 0.637 in farm $\mathrm{A} 4$ and $4.421 \mathrm{ds} . \mathrm{m}^{-1}$ in farm $\mathrm{A} 8$, with mean about $2.529 \mathrm{ds} . \mathrm{m}^{-1}$. While it ranged in the second soil depth $(30-60 \mathrm{~cm})$ from 0.533 in farm A3 and $3.580 \mathrm{ds} . \mathrm{m}^{-1}$ in farm A9 with mean about $2.057 \mathrm{ds} . \mathrm{m}^{-1}$ (fig 2). The results show that the values of the EC is less than the values obtained from uncultivated soils, and the reason for that is the existence of drainage network which cause a decreasing of $\mathrm{pH}$ of cultivated soils other than uncultivated soils. We found that EC values of soil samples were lower compare to the EC of the uncultivated soils except in two sites were the EC exceeded 4.0 at site $\mathrm{A} 8=4.4$ and $\mathrm{A} 9=4.2$. We think that rise of $\mathrm{EC}$ in these two sites only because of the elevation of the groundwater level due to problems and damage of the drainage net compare to the other sites. The results show that five farms were either slightly salinized or salted. In general EC in the first soil depth is higher than in the second soil depth although we expect that EC would be lower in the second depth than the first, because the salts will leached by irrigation into the lower soil depth. These results are consistent with the results reported by [26]. Saline soils have an EC $>4 \mathrm{ds} . \mathrm{m}-1$ at $25^{\circ} \mathrm{C}$ and $\mathrm{pH}<8.2$ [27]. The higher the EC the more salts are in the soil [15]. Soils are generally considered as saline when the EC is more than or equal to $4 \mathrm{ds}^{-1} \mathrm{~m}^{-1}$ equivalent to 40 $\mathrm{mM} \mathrm{NaCl}$, and exchangeable sodium percent of less than 15 with wide range of $\mathrm{pH}$ [28]

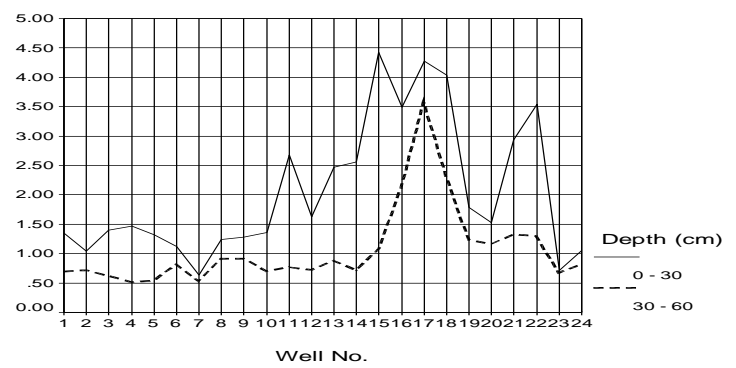

Fig. 2. Electrical conductivity of soil samples from the well farms

It had been reported, that there is non-problematic of an irrigation water with an EC of $<0.75 \mathrm{ds} . \mathrm{m}^{-1}$, but the irrigation water with an EC $0.75-3.0 \mathrm{ds} \cdot \mathrm{m}^{-1}$ may pose an increasing problem, while there is a severe problem with an irrigation water with an EC greater than $3.0 \mathrm{ds} . \mathrm{m}^{-1}$. [29]. The results here show that values of the Exchangeable Sodium Percent (ESP) ranged between $0.82-17.7 \%$ in the first soil depth, and $0.58-10.7 \%$ in the second soil depth (fig-3). ESP is the amount of sodium held in exchangeable form on the soil's cation exchange complex, however soils that have more than $6 \%$ ESP are considered to have structure stability problems related to potential dispersion [30]. These results show the ESP values exceeded 15\% in two sites, where in the first soil depth is 17.56 in A8, and 15.21 in site B9. We also noticed that ESP values in the first soil depth is high in all sites comparing to the second soil depth which could be due to the rising values of EC in the first soil depth. this result is consistent with the result reported by [31].

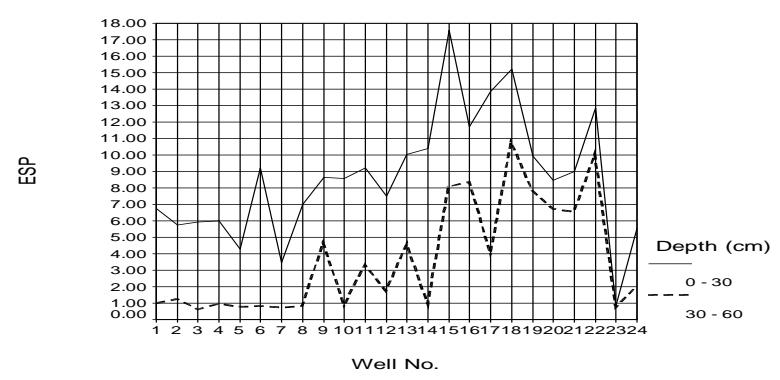

Fig. 3. Exchangeable sodium percent of soil samples for the well farms

Soluble salts can be leached out of the soil by excess water of sufficiently low salt content in present. So, ESP can only be lowered by chemical modification which replaces sodium adsorbed to the surface of soil particles with calcium and magnesium. [32]. According to the American Soil Classification of slightly or salinized soils, we can conclude that the soils effected with salinity represented about $8.3 \%$ whereas $91.7 \%$ were not affected. It had been estimated that about $50 \%$ of irrigated soils were salinized by human factors mainly as a consequence of improper methods of irrigation and poor quality water [33]. Capabilities of soils differ depending on the classified types, chemical and physical characterizes [34]. A possible interpretation for the increasing of salinity in the first depth $(0-30) \mathrm{cm}$ could be that the amount of irrigation water applied as 
sprinkler was not sufficient enough to leach or move the salts downwards, this result is in agreement with the results obtained by [35]. Salinity in the irrigated fields may also attribute of the waterlogging on the soil surface due to unleveled surfaces. We observed some farms were not level and had depressions on low lying farms. These farms acted as holders of water which after evaporation left some salts on the soil surface [36]. Accumulation of soluble salts possibly brought by salty groundwater to the surface, capillary rise of salty groundwater to the surface and accumulation of salts on surface has long been reported in arid soils [37]. As the area is located in arid region, high evaporation and transpiration rates in the area tend to decrease the limited amount of water available for leaching and transporting salts. Soil deeper than $60 \mathrm{~cm}$ might be had more salinity compared with the studied soil profiles, and that is attributed to salts leaching process to deeper zones due to excess irrigation application [38]. There is a close relation between soil salinity and the soil drainage conditions, poor drainage can lead to soil salinity [39]. We conclude that Salinity and slightly saline soils were observed in five farms, as we measured EC, pH, and ESP. in Fezzan area cultivated fields were prone to salinization processes mainly as a result of high level of groundwater, high temperature and improper irrigation ways.

IV. Acknowledgment

The researchers are would like to thank Sebha University for the financial and technical support.

\section{References}

[1] R. L. Dehaan, and G. R. Taylor, "Field-derived spectra of salinized soils and vegetation as indication of irrigation-induced soil salinization," Intr. J. of Remote Sensing, vol. 80, pp. 406-417, 2002.

[2] A. Fernández-Cirelli1, J. L. Arumí, D. Rivera, and, P. W. Boochs, "Environmental effects of irrigation in arid and semi-arid regions, Chilean," J. Agri. Res., vol. 69, pp. 27-40, 2009.

[3] P. Rengasamy, "World salinization with emphasis on Australian," J. Exp. Bot., vol. 57, pp. 1017 - $1023,2006$.

[4] J. D. Rhoads, "Use of saline and brackish water for irrigation implications and role in increasing food production, converging water, sustaining irrigation and controlling soil and water degradation," in R. Ragab and G. Pearce, Ed. Proceeding of International Workshop on "Use of saline and brackish water for irrigation implications, for the management of irrigation drainage Crops," Bali, Indonesia, pp. 23- 24. 1998.

[5] E. Huok, M. Frasier, and E Schuck, "The agricultural impacts of irrigation induced waterlogging and soil salinity in the Arkansas," Basin. Agri. Water Mange., vol. 85, pp. 175 - 183, 2006.

[6] E. Burger and A. Celkova, "Salinity and sodicity hazard in water flow processes in the soil and plant," Soil Envr., vol. 49, (7), pp. $314-320,2003$.

[7] B. A. Ould Ahmed, M. Inoue, S. Moritani, "Effect of saline water irrigation and manure application on the available water content, soil salinity, and growth of wheat," Agri. Water Manage, vol. 97, pp. $165-170,2010$.

[8] M. G. Barbour, J. H. Burk, W. D. Pitts, F. S. Gillan, and M. N. Schwartz, Terrestrial Plant Ecology, Menlopark, California: Benjamin / Cummings, 1998.

[9] H. B. Chaniho, I. Rajpar, U. A. Talpur, N. B. Sial, and Zia-ul-hassan. "Evaluating soil and groundwater salinity in TALUKA TANDO BAGO, SINDH. Pak. " J. Agri. Engg. Vet. Sci, vol. 26 (2), pp. $19-26,2010$

[10] R. W. Miller and R. L. Donahue, Soils in Our Environment, $7^{\text {th }}$ Ed. NJ: Prudence Hall, Englewood, Cliffs, 1995 , p.323.

[11] Irrigation Water Quality - Soil Compatibility: Guidelines for Irrigation in Saskatchewan, Saskatchewan Water Corporation,1987, p.60.

[12] A. Yahya, "Salinity effects on growth and on uptake and distribution of sodium and some essential mineral nutrients in sesame," $J$. Plant. Nutr. Vol. 21, pp. 1439 - 1451, 1998.

[13] R. Munns, R. A. James, and A. Lauchi, "Approaches to increasing the salt tolerance of wheat and other cereals," J. Exp. Bot. vol. 57, p. 1025, 2006.

[14] J. Shalhevet, "Using water of marginal quality foe crop production: major issues," Agri. Water Manage, vol. 25, pp. 233 - 269, 1994.

[15] A. D. Blaylock, Soil Salinity, Salt Tolerance, and Growth. Potential of Horticultural and Landscape Plants. Department of plant, Soil, and Insect Sciences, College of Agriculture, University of Wyoming, B-988, 1994.

[16] E. V. Mass, "Crop salt tolerance: agricultural salinity and assessment management," American Society Civil Engineering Manuals and Reports on Engineering, No. 71, pp. 262 - 304, 1990.

[17] A. Chandra, W. Madramootco, R. Johnson, and S. W. Lyman, "Management of agricultural drainage water quality," FAO. Water Reports, 13, ch. 2, 1997.

[18] J. Al-danasuri, Geography of Fazzan: A Regional Study, Tripoli: Dar - Libya for Publication and Distribution, 1967.

[19] M. L. Jackson, Soil Chemical Analysis, N.J.: Prentice Hall INC., Englewood cliffs, 1958.

[20] M. A. Franson, "Standard methods of the examination of water and wastewater," Ed. 19 ${ }^{\text {th }}$ American Public Health Association, Washington, USA, 1995.

[21] R. S. Ayers, and D. W. Westcot, "Water quality for irrigation," FAO of the United Nations, Rome, Italy, pp.174, 1985.

[22] S. Yadav, M. Irfan, A. Ahmad, and S. Hayat, "Causes of salinity and plant manifestations to salt stress: a review," J. Envir, Biol, vol. 32, pp. $667-685,2011$.

[23] K. M. Auwad, "Principles of soil chemistry," Ministry of Higher Education and Scientific Research, University of Basra, Iraq, 1986.

[24] H. Ghadiri, J. Hussein, E. Dordipour, and C. Rose, "The effect of soil salinity and sodicity on soil erodibility, sediment transport and downstream water quality," $13^{\text {th }}$ Inter- Soil Conservation Organization Conf., paper No. 631, pp. 1 - 6, 2004.

[25] G. I. Metemicht, and J. A. Zinck, "Spatial discrimination of salt and sodium - effected soil surfaces," Intr. J. of Remote Sensing, vol. 18 , pp. $2571-2586,1997$.

[26] B. Idris, and N. A. Suat, "Subsurface drainage and salt leaching in irrigation land in south - east Turkey," Irrigation and Drainage, 3 (58), pp. $346-356,2009$.

[27] L. A. Richards, "Diagnosis and improvements of saline and alkali soils," US Salinity Laboratory DA, US Department of Agriculture hbk 60, p. 160,1954 .

[28] R. Munns, and M. Tester, "Mechanisms of salinity tolerance," Ann. Rev. Plant Biol., vol. 59, pp. 651- 681, 2008. 
[29] R. S. Ayers and D. W. Westcot, "Water quality for agriculture," FAO Irrigation and Drainage Paper No. 29 (Rev.1), Food and Agriculture Organization of the United Nations, 1976.

[30] R. Van de Graaft and R. Patterson, "Explaining the mystery of salinity, sodicity, SAR and ESP in in-site practice," in proceeding of On-site '01 Conference, Advertising On-site Wastewater Systems, Ed. R. A. Patterson \& M. J. Jones, Lanfax Laboratories, Armidale, 2001, pp. $361-368$

[31] S. Kale, "Impact of drained and un-drained soil conditions on water table depths, soil salinity and crop yields," African J. of Agri. Res., vol. 7(19), pp. 2935 - 2945, 2012.

[32] J. W. Bauder and T. A. Brock, "Irrigation water quality, soil amendment, and crop effects on sodium leaching," Arid Land Research and Management, vol. 15, pp. $101-113,2001$

[33] I. Szaboles, "Salinization of soils and water and its relation to desertification," Desertification Control Bulletin, vol. 21, pp. 32 - 37, 1992.

[34] M. Cetin, and H. Ozcan, "Problems encountered in the irrigated and non-irrigated area of the lower Seyhan plain and recommendations for solution: a case study," Tr. J. Agri. For., vol. 23(1), pp. 207 - 217, 1999.

[35] N. Maraka, "A contribution to the weather and meteorological studies of Bophuthatswana, with special emphasis on the rainfall distribution and its applications to agro meteorological activities," Department of Transport, Meteorological Services, Mmabatho, South Africa, 1987.

[36] S. A. Materechera, "Soil salinity in irrigated fields used for urban agriculture under a semi-arid environment of South Africa," Afr. J. of Agri. Res, vol. 6 (16), pp. 3747 - 3754, 2001.

[37] Z. Samdani, "Salinization threatens irrigation," Economic and Business Review, Daily Dawn, Karachi. III, 6, pp. 3 - 9, 1995.

[38] H. Kaman, M. Cetin, and C. Kirda, "Monitoring and assessing of changes in soil and groundwater salinity of Yemisli Irrigation District of Turkey using low quality irrigation water," Sci. Res. and Essays, vol. 6 (6), pp. 1388 - 1396, 2011.

[39] V. Kovda, "Evaluation of soil salinity and waterlogging," FAO Soil Bulletin, 31, Rome, 1975.

\section{Authors' Profile:}

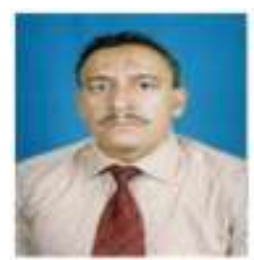

Mansour Awiedat Salem was born in Geera, Brack, Al Shaati, Libya in 1959. He has obtained both M.phil.(1993) and PhD (1996) in Biochemistry from Swansea University, Swansea, UK.

He was the Head of the Department of Environmental Sciences, Faculty of Engineering and Technology, Sabha University, Libya from 1997 to 2005. Then, he joined as the Associate Professor and Dean of Faculty of Education, Brack, Al Shaati under the same University and still holding the position.

Dr.Awiedatss has received trainings in Operation and Using of Gas Chromatography and Operation and Using of Atomic Absorption Spectroscopy.He was the member of Environmental General Authority, Libya from 2007 to 2010 and also the Head of this office during 2010-2011.

Latif H. Al-ethawi is a faculty member in Environmental Science in Faculty of Education, Sabha University, Sabha, Libya. 